\title{
Tropical Gothic: literary and creative works
}

\section{Anita Lundberg, Roger Osborne, Katarzyna Ancuta \& Agnieszka Stasiewicz-Bieńkowska}

James Cook University, Australia; Chulalongkorn University, Thailand; Jagiellonian University, Poland

\begin{abstract}
The eTropic special issue on the theme Tropical Gothic was first conceived in 2017. From the beginning there was a sense of how the theme had a certain resonance. By 2018, the term had appeared as a hashtag in social media for new music album entitled Tropical Gothic.

These resonances are important as they reveal the build up of an idea at a particular time. This paper follows a rhizomatic path as it traces Tropical Gothic through the creative works of a music album, its cover art, and further to other influences including film and literature.

These literary and creative works likewise resonate with the papers brought together in this second issue on the theme Tropical Gothic.
\end{abstract}

Keywords: Tropical Gothic, literature, creative works, music, cover art, film, rhizomatics, demon 


\section{Hashtag Tropical Gothic}

$\mathrm{E}$ ntering the hashtag \#tropicalgothic into the social media search bars of Facebook and Twitter in early 2018 would bring up a music album just being released, cover art for the album, and further links to several literary and creative works. The seeming randomness of how the hashtag brought these different fields together is a reminder of the anthropologist Gregory Bateson's famous words: "What is the pattern that connects the crab to the lobster and the orchid to the primrose, and all four of them to me? And me to you?" (1979, p. 8). This 'koan' from Bateson's ecology of mind project $(1972 ; 1979)$ explores the connectivity of patterns. A broad and inclusive thinker, here Bateson is weaving anthropology, early network theory, and images into an interdisciplinary practice that was inspired by his ethnographic fieldwork in Bali which ranged across art, dance, trance, drama and music, and his reading of Alfred Russel Wallace's The Malay Archipelago (1890 [1869]) where the co-theorist of evolution observes the interdependence of natural systems. Entwining notions of cyber networks, environmental ecologies, and systems of thought, Bateson's 'ecology of mind' has in turn influenced several contemporary theories, including the philosophy of rhizomatics (Deleuze \& Guattari, 1987; Lundberg, 2013).

This editorial follows a rhizomatic path in order to explore the 'tropical gothic' works that emerged through the internet search back in 2018, before the publication of eTropic's two-part special issue on Tropical Gothic. Rhizomatics is particularly evocative of the tropics. The philosophy was envisioned by Deleuze and Guattari (1987) as an image of thought based on the botanical rhizome - which includes plants such as gingers, turmeric, bamboo, sympodial orchids and the Venus flytrap. The root system of rhizomes forms horizontal networks in which nodes of the root may spread out in any direction. In turn, nodes hold the potential to multiply, creating ever growing networks. If cut from its root network and replanted, a node will continue to grow - forming a new root network and sprouting forth a plant. This pattern of growth is emblematic of rhizomatic theory, for there is no origin or hierarchy in the rhizome: every node holds the potential to connect and expand, to start anew (Deleuze \& Guattari, 1987; Lundberg, 2013). In Deleuze and Guattari's work, the horizontal and pliable network image of rhizomes is juxtaposed to the rigid hierarchical image of the tree with its deep penetrating roots, upright trunk and radial branches - the arboreal image upon which traditional Western philosophy bases notions of evolution, development, progress, and knowledge; the same ideals that strongly underpinned colonialism. However, Deleuze and Guattari's philosophy is not in any simple way anti-tree. The tropical banyan tree, 
with its spreading branches that drop down tendrils to the ground, which sprout roots to form new trunks, that then branch out to create an expansive network of a tree, is an especially poignant rhizomatic image (Lundberg, 2008, 2013). Rhizomatics, in short, is non-linear, it invites multiplicities and wanderings.

In this introduction to the special issue Tropical Gothic: Literary and Creative Works, we undertake such a wandering - trying to avoid notions of hierarchies of ideas and preconceived directions. However, such an undertaking is never aimless, for our interest is to explore the tendrils of literary and creative works that draw together a sense of the dense Gothic Tropics.

\section{Tropical Gothic: a music album}

That a music album appeared from the \#tropicalgothic search seemed a random result - perhaps because initially the search was embedded in a scholarly desire to uncover important classical literature or references to academic articles on the theme. Yet, there was also a certain appeal to this unexpected find - the idea that the theme Tropical Gothic was in the process of being created in different fields across divergent parts of the world.

The album's sound track titles likewise indicate a geographical and cultural spread of the notion Tropical Gothic. Side A, entitled 'Onibaba', consists of eight musical tracks: 'The Pit', 'A Mask of Flesh', 'By the River', 'Samurai', 'Shindo's Blues', 'La'ap Blues', 'Running Naked' and 'Onibaba'. These short pieces evoke changing moods. The first track 'The Pit', as the title suggests, is deep and dark with a hint of horror. The following tracks continue to conjure various scenes / sceneries all suggesting a brooding tempest, until suddenly, bursting from cumulous clouds, you are 'Running Naked' on a dazzling sun-drenched beach, before settling into a contemplative, cerebral finale in 'Onibaba'.

In contrast to Side A, the B side, labelled 'Legong', is one long musical piece called 'Legong/Gods of Bali'. For eighteen minutes sounds morph between high pitched dulcet bells - reminiscent of the Balinese gamelan orchestra (but, in fact, having nothing to do with gamelan) - and dark undertones. Here the use of soundtracks from silent films and discordant rhythms mix with steel guitar to create a mesmerizing effect. As described by Angelo Borelli in The New Noise, these are "hallucinated vibraphone sounds, which 


\section{eropic}

eTropic 18.2 (2019) 'Tropical Gothic: Literary and Creative Works' Special Issue | 4

dance as you bundle up to exhaustion, up to the song that is the song of the cicadas and that of birds [and] an omen of misfortune" (Borelli, 2018).

The album is by Mike Cooper (2018), a veteran of music creativity known for its 'ambient/electronic/exotica' and Pacific elements - for example in albums entitled 'Kiribati' (1999) and 'Rayon Hula' (2004) - as well as other experimental genres that are invoked through steel lap guitar mixed with his own field-recorded soundscapes. (Boomkat.com, 2018). As Cooper states of his album - with an obvious appropriation of the academic work of Edwards and Vasconcelos (2016) - "Tropical Gothic examines Gothic within a specific geographical area of 'the South'...as well as transnational movements of the Gothic...Tropical Gothic includes, but is by no means limited to, a reflection on a region where European colonial powers fought intensively against indigenous populations and against each other for control of land and resources." (Café Oto, 2018).

The music was inspired particularly by the composer's interpretation of two films. Side A references Kaneto Shindo's, classic horror film Onibaba (1964); and Side B is an homage to Henri de La Falaise's film, Legong - Dance of the Virgins (1935).

The sound tracks of Side A reference not only the film title 'Onibaba' [The Demoness], but also the director himself, in 'Shindo's Blues', as well as significant scenes from the film in the tracks 'The Pit', 'The Mask of Flesh', 'By the River', and 'Samurai'. Set in C14th Japan during a period of warring shogunates, a peasant woman and her daughter-in-law survive in a hut near a river surrounded by marshes of the giant rhizome grass called susuki.

When weary samurai escape to the swamp to hide, the two women slaughter the warriors - dropping the dead bodies into a pit and trading their armour for rice. When their neighbour defects from the war and returns home, they learn that their son/husband was killed. The neighbour seduces the young widow, who sneaks out of the hut at night to have sex. One night a lost samurai - wearing a Hannya mask (representative of a jealous female demon) - comes upon the hut and forces the lone older woman to guide him out of the bewildering maze of the susuki swamp. Instead, the woman lures him to the pit. He falls to his death and she climbs down to take his possessions. Removing the mask, she sees he is disfigured. She uses the demon mask to haunt her lustful daughter-in-law, blocking the path to her lover's hut. 
However, one night during a storm, the mask sticks to her face and on its final removal she finds she is covered in disfiguring sores. The young woman, thinking she is a demon, flees - pursued by the mother-in-law, screaming that she is human. The younger woman jumps across the pit; as the older woman jumps after her, the film ends.

The Gothic eeriness of this classic horror film is poetically evoked through the black and white cinematography and the variously angled shots of the overwhelming susuki grass as it is stirred by the wind.

Side B of the album entitled, 'Legong/Gods of Bali', is, as Cooper states, inspired by the film Legong - Dance of the Virgins, one of the last silent films, and last motion picture shot in Two-Colour Technicolour. Featuring an all-Balinese cast, the filming took place mainly in the village of Ubud, Bali, in 1933. Directed by the Marquis Henri de la Falaise - the third ex-husband of movie star Gloria Swanson - the film was produced by his second wife, the screen siren Constance Bennett, through her company Bennett Pictures. The title of the film refers to the renowned Balinese Legong dance, which is performed by young virgins and accompanied by the traditional gamelan orchestra.

The plot is ostensibly a tragic love story. Poutou has been selected as one of her village's legong dancers. She is attracted to the young gamelan player Nyong, but Nyong's love interest is in Saplak, Poutou's half-sister. Nyong and Saplak meet clandestinely in groves and on bridges; however, they are seen together and their secret is exposed. Dejected, Poutou ends her life by jumping from a high bamboo bridge that spans a deep ravine into the boulder-strewn river below. The film ends with the cremation ceremony for Poutou's body.

Legong: Dance of the Virgins is punctuated by scenes of everyday Balinese life such as the marketplace, a cockfight, and extended sequences devoted to Legong and Djanger dances, as well as the Barong temple dance. The emotional intensity of this ritualised dance reaches a climax when Barong, performed by two dancers in the elaborate costume of the mythical lion-like beast who protects the community, confronts the witch Rangda, the personification of death and destruction, performed by a male dancer wearing a costume that includes a grotesque mask, wild hair, long fingernails and pendulous breasts. During the battle, the followers of Barong go into trance and try to attack Rangda with their kerises (knife-swords). But Rangda thwarts their attack, and, through her powers, turns the men's kerises upon their own chests. 
The struggle of Barong and Rangda - of good and evil - is played out as the men struggle with their kerises, which Rangda drives towards their hearts and Barong stops from penetrating. Here the film's intertitles - which make exaggerated claims about "sham suicides" and "courage born of madness" are unhelpful in understanding the significance of the Barong-Rangda dance, a centuries-old ritual that reenacts the balancing forces of nature. Rather than an uncontrolled display of primitive passions, the enactment of this trance-dance brings the forces of the world into equilibrium (Bloom \& Hagedorn, 2013).

The 'exotic' and 'erotic' Balinese mise-en-scène - including bare-breasted women contributed to the success of the film at the box office (playing for a long ten-week run at the New York World Theater in 1935) (Bloom \& Hagedorn, 2013). This is an example of a genre of interwar narrative films shot in exotic locales, which adapted indigenous culture to Western consumer tastes in a form of culture exploitation. Such films also implied the fantasy of female promiscuity amid strange exotic and demonic rituals, set in fecund tropical landscapes.

The cinematic inspiration for the musical works collected under the title 'Tropical Gothic', resonate with the concerns of eTropic's special issue. Similarly, the cover art for the album is suggestive of tropes of the Gothic Tropics.

\section{Tropical Gothic: Album Cover Art}

The album's cover is by the artist Evan Crankshaw. He states that the art was "inspired by (the tropical gothic) films Onibaba and Legong" and notes that it "attempts a synthesis of the two using images supplied by Mr Cooper" (Crankshaw, 2018). Those images include poster art for the film Onibaba showing eyes rising above swaying grass, and a still frame of the head of the lion-beast Barong from the film Legong: Dance of the Virgins.

The overall effect of the cover art (front and back) evokes a Balinese atmosphere. Amid a dense landscape of rice terraces, coconut palms, broad leaf flora, banyan trees, a bamboo bridge spanning a ravine, and local people going about daily chores, is the album title 'Tropical Gothic' - inscribed in gothic font. Rising above the title are the looming eyes of a demon. 


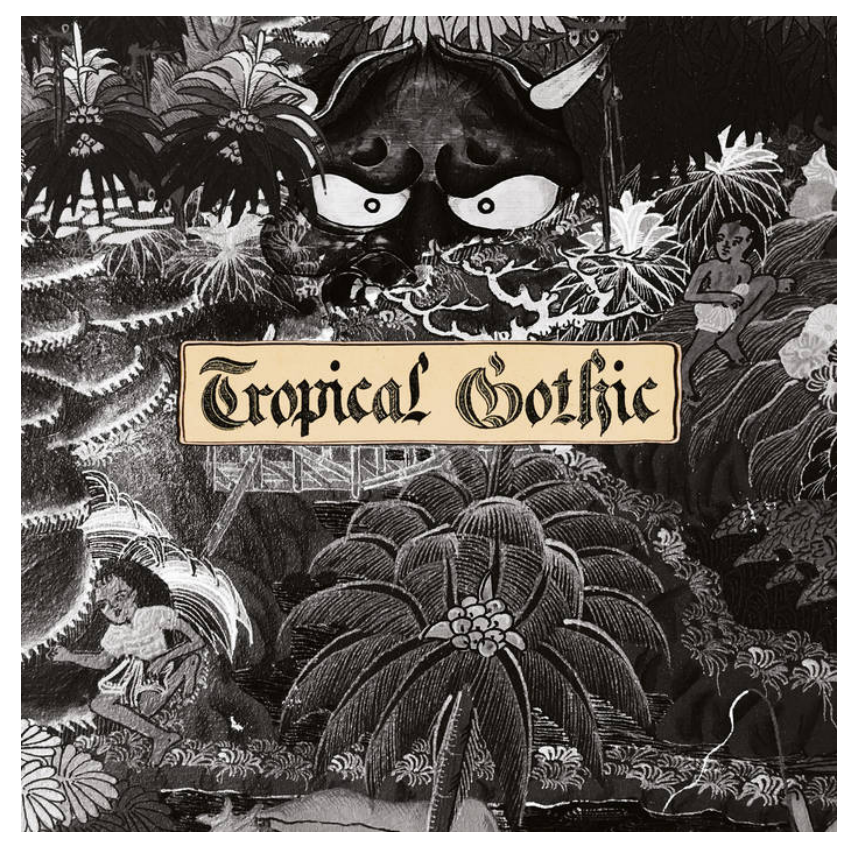

Figure 1. Tropical Gothic, album cover by Evan Crankshaw (front cover).

The demon resembles Bhoma, the carved figure that appears on gateways into sacred parts of Balinese temple complexes and on cremation towers. Bhoma - the offspring of Dewa Wishnu, god of rain, and Dewi Pertiwi, goddess of earth - symbolises verdant growth and jungles. Although it looks like a fierce and monstrous demon, he is a protector, scaring away evil spirits. In wider South and Southeast Asia, a demon's head is likewise carved into the lintels of inner gates to Hindu and Buddhist temple complexes. This demon is Kirtimukha 'glorious face' - often referred to as Kala in Southeast Asia - and it again acts as an awe-inspiring guardian of the threshold. Kirtimukha is the swallowing monster, the devourer associated with eclipses of the sun and moon (Eiseman, 1996).

As with the album's musical compositions, the artwork conjures up an omen of misfortune. It suggests that within the lush and exuberant setting of the tropics, demonic forces loom. 
eTropic 18.2 (2019) 'Tropical Gothic: Literary and Creative Works' Special Issue | 8

\section{Tropical Demons}

In the novel Island of Demons by Nigel Barley (2009), the image of Bhoma is associated with Kirtimukha and serves as a forewarning of the demise of a particular period of intense Western artistic and intellectual interest in Bali. Set mostly in Ubud of the 1920s and $30 \mathrm{~s}$, the novel relates the fictionalised story of the artist, composer, musicologist, curator, film producer and untrained ethnographer, Walter Spies - as narrated from the viewpoint of fellow artist, and resident of Ubud, Rudolf Bonnet. The novel intermixes this early Western fascination of Bali as a paradise, with partial biographies of many intellectual and popular celebrities that visited and researched the island at the time, including: artists Spies, Bonnet, Jean Le Mayeur and Miguel Covarrubias; the composer Colin McPhee; dancers Beryl de Zoete and Katharane Mershon; writers Vicki Baum and H.G. Wells; actors Charlie Chaplin, Noël Coward and Barbara Hutton; film directors and producers Baron Viktor von Plessen, Constance Bennett and Henri de la Falaise; and anthropologists Jane Belo, Margaret Mead and Gregory Bateson. The novel evokes a Gothic sensibility of a paradise steeped deep in underlying currents of forbidden intrigues and brutal realities - including colonialism and the horrors of World War. As a German national in the Dutch East Indies during WWII, Spies was arrested and interned. In 1942 the prisoners were released to be deported to Ceylon (Sri Lanka). The ship Spies boarded was hit by a Japanese torpedo and the prisoners, locked below deck, all drowned. In the novel, the sinking occurs on a full moon night of an eclipse and Bhoma is evoked as the great swallowing demon - consuming not only Spies, but bringing to an end a particular period of the island, which, as Adrian Vickers (1977) demonstrates, was created as a lush and erotic Bali of the European imagination. This Bali was a tropical paradise that had become an extension of salon life for the rich and famous, providing inspiration for artists and Hollywood writers - Bali and the Balinese became a form of consumption.

The Island of Demons suggests a pantheon of demons: inner demons of private psychological struggles for Western seekers of paradise; sacred demons that are always present as part of the island's beliefs, which the Balinese must keep in balance through an endless cycle of intricate and elaborate rituals of dance, drama, costume, music, offerings, cremation ceremonies, and prayers; and the demonic forces of world events that encroach on and begin to devour this tropical world - forces such as colonialism, imperialism, tourism and capitalism.

These images of the demonic entwining the paradisiacal, of encroaching shadows on sun-drenched landscapes, and the looming vision of devouring monsters, are leitmotifs in Gothic literature and creative works which are expressly concerned with the tropics.

As Daniel Serravalle de Sá (2010) recognises: 
eTropic 18.2 (2019) 'Tropical Gothic: Literary and Creative Works' Special Issue | 9

Establishing the concept of Tropical Gothic as a critical term to investigate specific cultural traditions of the supernatural and the strange in the warmer parts of the globe is not an easy task. At first glance the expression itself seems to be rather contradictory; an oxymoron that combines the opposing ideas of 'solar' and 'gloom' in one concept.

\section{Gothic in the Tropics}

Gothic fiction emerged in the eighteenth century with Horace Walpole's The Castle of Otranto (1764), and has since evolved and been adapted into a diverse array of art forms, including novels and short stories, films, computer games, and visual art. In the nineteenth century, novels such as Mary Shelley's Frankenstein, Edgar Allan Poe's short stories and Bram Stoker's Dracula took their place as prominent models of Gothic fiction. In the twentieth century, elements of the Gothic were deployed in the fiction of American writers such as William Faulkner and Flannery O'Connor, introducing the Southern Gothic to the lexicon of creative writers and filmmakers. As the film and television industry developed at pace throughout the twentieth century, the visual representations of the Gothic more commonly found in the galleries of art museums were increasingly encountered in cinemas and television screens of the family home. The growth of the Gothic in various forms and platforms in regions beyond Europe and the South of the United States eventually influenced creative writers and artists in the colonies of European powers, particularly in the tropical regions that feature in this special issue devoted to Tropical Gothic.

Recent publications demonstrate interest in the Gothic across a broad band of tropical regions. Edwards and Vasconcelos (2016) collect a range of essays on fiction and poetry that examine 'Tropical Undead', 'Tropical Chill', and 'Social and Political Landscapes of the Tropical Gothic' in the 'South' of the Americas. The essays collected in Casanova-Vizcaino and Ordíz (2017) examine literature, visual arts and culture in Latin America in an attempt to determine whether such a thing as 'Latin American Gothic' exists, including such determinations within an understanding of the Gothic as a global phenomenon with particular local manifestations. Such approaches inspire work in postcolonial Gothic (Byrne, 2018) and "Gothic supernaturalism in the 'African Imagination"' (Duncan, 2019, Montgomery, 2019) or comparative studies of the influence of eighteenth century British Gothic on Brazilian poets (de Barros \& de 
eTropic 18.2 (2019) 'Tropical Gothic: Literary and Creative Works’ Special Issue | 10

Oliviera, 2017). But, as Edwards and Vasconcelos (2016) argue, in contrast to the North Atlantic Gothic tradition, the "[s]unlit and humid conditions [of tropical regions] form a hotbed where Gothic figures - ghosts, zombies, vampires - move freely through plantations, houses and tropical cities, haunting the bright landscape and forming the basis for tropical chills" (p. 2). Under such conditions creative writers and artists explore the "social and political issues of gender, race and identity formation" and "cultural anxieties involving class and difference" (p. 5).

Across the Pacific in Australia, the Tropical North of that southern hemisphere continent is frequently characterised in Gothic terms. The novelist Thea Astley acknowledged the influence of writers in the Southern Gothic tradition such as William Faulkner and Flannery O'Connor (Richey, 1986), demonstrating the trans-national reach of Gothic tropes. Carter (2010) demonstrates the importance of tropical settings in this Antipodean version of the Gothic, arguing that "[s]uch a landscape could be romantic and inspiriting, but it was also full of menace or mystery in its potential 'inhumanity'" (para. 13). These settings continue to influence the production of creative writers and playwrights. In the tropical regions of Australia, "more Gothic-themed plays [have been] produced on the professional stages of Brisbane, Cairns, and Darwin than in the rest of the nation combined" (Stadler, Mitchell \& Carlton 2015, p. 88), demonstrating the emergence of a "distinct modality in the Australian North" that inspires the imagination of writers, artists, filmmakers, readers and audiences alike.

In Asia, the term Tropical Gothic was first coined in 1972 by the Filipino writer Nick Joaquin as a title of a collection of his short stories. Filled with a cast of melodramatic characters, the stories evoked nostalgic memories of pre-colonial Philippines and the baroque excesses of the Spanish colonial past, of magic and folklore infused with Catholic rites. Throughout the region, Gothic tropes have been employed to account for the horrors of colonialisation that reduced the colonial/racial Other to "the ghost from the empire" (Khair 2009, p. 10), seen as "a threat and a source of terror" (p. 169). In postcolonial texts, folklore and myth are mobilised to weave fantasies of the pre-colonial past and account for the hybridisation of modern Asian tropical cultures. Asian Tropical Gothic draws heavily on folklore and the regional collective imaginary, imbuing centuries-old animistic spirits with agency and turning them into markers of local identity. Indigenous supernatural entities like the pontianak, kuntilanak, phi krasue, phi pop, aswang and many others refuse to be defined within the narrow Western categories of ghosts, monsters, vampires or zombies. These essentially liminal 
creatures are often simultaneously dead and alive, natural and supernatural, material and immaterial, good and evil, traditional - and always ready to redefine themselves.

Asian tropics are always intrinsically linked with the tropical forest where the were-tiger is the king. Unlike the were-wolf, the were-tiger is not a mere shapeshifter influenced by the cycles of the moon - it is a sacred being and a man-eater in one, a man turned into a tiger or a tiger turned into a man (cf. Brighenti, 2017). In Tropical Gothic texts, the excessive tropical jungle makes for a terrifying adversary - it is impenetrable and unfathomable to humans. In more contemporary texts, however, the past splendor of the Gothic wilderness is used to offset the more realistic portrayals of the current state of the Asian tropics, where rapid urbanisation tied to pollution, excessive deforestation and river regulation has brought the region to the brink of environmental disaster. Other texts focus on human-centred horrors, re-evaluating the region's troubled history, reopening the cultural wounds and dealing with individual and collective traumas brought about by the succession of changing regimes and internal conflicts. Deep-ingrained social inequality and discrimination against one's gender and sexuality, race and ethnicity, religion and caste are common themes frequently explored within the Gothic framework. Though few Asian books are consciously branded as 'Gothic', there is no doubt that the works of such writers as K.S. Maniam, Eka Kurniawan, Yangsze Choo, Chart Korbjitti, Vikram Chandra, or S.P Somtow have greatly contributed to legitimising the Gothic within tropical Asian settings.

As the collection of papers in the previous part of this two-piece special issue showed, "the Tropical Gothic of today provides a space of reflection upon the unique social, historical, political, cultural and environmental conditions of the tropics" (Lundberg, Ancuta \& Stasiewicz-Bieńkowska 2019, p. 4). In this second part, we argue that creative writers and artists have a particular role to play in such reflections, through producing the cultural artefacts for the contemplation of others, or by contributing to such debates as creative practitioners and critics. Through these creative acts we approach a deeper understanding of the human condition in the tropics and beyond.

\section{Literary and Creative Works}

This special issue of eTropic opens with Tania De Rozario's 'Death Wears a Dress', a collection of three poems that takes us into the supernatural worlds of Asian female ghosts. In 'Appetite', the edible and the bodily collapse into one another, creating a deliciously macabre effect. A voracious devouress plays with words and flavours to lure 
the reader into a cannibalistic dance of desperate yearning for fulfilment, completion and ultimate communion. The second poem, 'On Losing One's Head', looks into the woman's loss of Self through the images of the vulnerable and dismembered female body gazed upon by its ghostly former wearer. In the last poem, 'Motherhood', De Rozario juxtaposes the imageries of death and newborn life, an unbearable weight and ever-deficient sacrifice, to inquire into the physical and emotional burdens of motherhood.

The female specter returns in Jessica Faleiro's 'Dancing with Rita', a short story rooted in the Goan oral tradition. Set in Goa, South India, it evokes the atmosphere of the tropics with heat and humidity, dancing fireflies, luscious floral fragrances and still air awaiting the monsoon season. Weaved into the rich tropical scenery, Faleiro spins the Gothic tale of violence, murder, family abuse, betrayal and, above all - a doomed love between a man and a ghost girl. 'Dancing with Rita' is also a fine example of the LusoIndian perspective on the cultural scene of the post-colonial India.

The next two short stories, 'Apocalypse' and 'The Riddle of the Fowl and the Eagle', invite the reader into the fictitious universes of Alvin Yapan, translated from Filipino into English by Christian Benitez. Set in a forsaken corner of an unnamed Philippine city, 'Apocalypse' is a tale of uncontrollable female sexuality that results in monstrous pregnancies, non-human offspring, death and decay. 'The Riddle of the Fowl and the Eagle' draws on the eco-Gothic, exploring the uncertainties surrounding the questions of identity and justice, and the blurry lines between the animal and the human. Both are tales of the boundaries transgressed, where human blends with non-human, reality disintegrates into the fantastic, and the cultural, the natural, and the supernatural mix together. They are also, however, stories of loneliness and ultimate alienation - of screams in the night, unheard or dismissed as taken for one's own.

The question of the boundaries between the human and the animal are further investigated in 'Cage 14: The Orangutan', a creative non-fiction work by Christina Yin. Through the interviews with people that knew and took care of him, Yin traces the story of the orangutan named Bullet from Sarawak, Malaysian Borneo. Weaving together the facts of his life, the contemplation of his possible feelings and reception of the world around him, and the folkloric tales of orangutans, the author creates a compelling vision of a humanised animal troubled with his position as the non-human, and touches upon the dilemmas of wildlife preservation. 
Ecocritical anxieties and the fears of environmental disaster are further articulated in Robyn Glade-Wright's 'Plastic Gothic: Frankenstein, Art and the Microplastic Monster'. Glade-Wright employs her work of art Microplastics Found in Human Embryo to convey the horrors of plastic pollution and to stress the urgent need for a decisive response. She draws an interesting parallel between microplastic contamination and Frankenstein's monster - rendering both as highly advanced yet uncontrollable and ultimately disastrous scientific creations. At a time when tropical waters are choked with plastic pollution, the most devastating effect of which is the degradation of wildlife and the transformation of unfortunate animals, including humans, into grotesque halfbeast-half-plastic hybrids, Glade-Wright's artwork engages with the themes of tropical eco-Gothic to sound a call-to-action for environmental preservation.

The final two stories take us deep into the Australian tropics. In 'A sweltering afternoon: Herberton, Far North Queensland' by Tass Holmes, a drive through the dry eerie landscapes on the way to the mining town of Herberton stirs a memory of the narrator's childhood. As past and present narratives intertwine, the previously blurred recollections come into focus with a new intensity. Lianda Burrow's story, 'Not Today, Old Man' follows a journey of a mother and a daughter, which brings them closer together and simultaneously distances them from the recollections of domestic violence they both experienced. Burrow investigates the cyclical nature of the relationship between women and violence, where daughters who grow up in an abusive environment in time inevitably navigate towards their own abusers. The bond between the two women reflects the understanding they share as survivors.

\section{Rhizomatic tendrils}

The rhizomatic pathways blazed by many of the writers, artists and critics who have interrogated the human condition in the tropical regions of the planet exhibit significant traces of the Tropical Gothic. The stories, poems, visual art and related commentary collected in eTropic each add new tendrils to this constantly evolving mode of enquiry. We hope that these special issues inspire further creative and critical work that grow out of the emerging texts and traditions of the Tropical Gothic. 
eTropic 18.2 (2019) 'Tropical Gothic: Literary and Creative Works' $\quad$ Special Issue | 14

\section{References}

Barley, N. (2009). Island of Demons. Singapore: Monsoon Books.

Bateson, G. (1972). Steps to an Ecology of Mind: Collected Essays in Anthropology, Psychiatry, Evolution, and Epistemology. Chicago, III: University of Chicago Press.

Bateson, G. (1979). Mind and Nature: A Necessary Unity. (Advances in Systems Theory, Complexity, and the Human Sciences). New York, NY: E. P. Dutton.

Bloom, P.J. \& Hagedorn, K.J. (2013). 'Legong: Dance of the Virgins'. San Francisco Silent Film Festival http://www.silentfilm.org/legong-dance-of-the-virgins

Boomkat (n.d.). https://boomkat.com/products/tropical-gothic

Borelli, A. (2018). 'Mike Cooper: Tropical Gothic'. The New Noise. Retrieved from https://www.thenewnoise.it/mike-cooper-tropical-gothic/ 22 November.

Brighenti, F. (2017). Traditional Beliefs about Weretigers among the Garos of Meghalaya (India). eTropic, 16 (1), 96-111.

Byrne, E. A. (2018). The Globalised Garden: Jamaica Kincaid's Postcolonial Gothic. Wagadu: a Journal of Transnational Women's \& Gender Studies, 19, 77-90.

Café Oto (2018). Retrieved from: https://cafeoto.co.uk/events/tropical-gothic-mike-cooper/

Carter, D. (2010). Imagination: How people have imagined Queensland. Queensland Historical Atlas: Histories, Cultures, Landscapes. Retrieved from: https://www.qhatlas.com.au/essay/imagination-how-people-have-imagined-queensland.

Casanova-Vizcaíno, S., \& Ordiz, I. (2017). Latin American Gothic in Literature and Culture. Routledge.

Cooper, M. (2018). 'Tropical Gothic' Vinyl LP/Digital Album. Released by Discrepant: London, UK. October 5.

Crankshaw, E. (2018). Twitter @flashstrap, 22 Aug.

de Barros, F. M., \& de Oliveira, M. A. (2017). Brazilian Gothic in Carlos Ferreira's poetry/O Gotico brasileiro na poesia de Carlos Ferreira. Soletras, 17(34), 70-87.

Deleuze, G. \& Guattari, F. (1987). A Thousand Plateaus. (Vol. 2 of Capitalism and Schizophrenia) (B. Massumi, Trans.). Minneapolis, MN: University of Minnesota Press. (Original work published 1980).

de Sá, D.S. (2010). Tropical Gothic. Rome, Italy: Arachne.

Duncan, R. (2019). Gothic supernaturalism in the 'African imagination'. Routledge Handbook of African Literature.

Edwards, J.D. \& Vasconcelos, S.G. (2016). Tropical Gothic in Literature and Culture: The Americas. New York, NY \& Oxon, UK: Routledge.

Eiseman, F.B.Jr. (1996). Bali: Sekala \& Niskala: Essays on Religion, Ritual, and Art. North Clarendon, VT: Tuttle Publishing.

Falaise, H. de la (Director) (1935). Legong: Dance of the Virgins [Motion Picture]. USA: Bennett Pictures Inc.

Joaquin, N. (1972). Tropical Gothic. St Lucia, QLD: University of Queensland Press.

Khair, T. (2009) The Gothic, Postcolonialism and Otherness: Ghosts from Elsewhere, London: Palgrave Macmillan.

Lundberg, A., Ancuta, K. \& Stasiewicz-Bienkowska, A. (2019). Arts, Humanities and Social Sciences. eTropic, 18 (1), 1-11. 
Lundberg, A. (2013). TransOceanik Links: Research Networks and the Space-Place of Colloquia. eTropic, 12 (1), 1-21. DOI: https://doi.org/10.25120/etropic.12.1.2013.3351

Lundberg, A. (2008). Material poetics of a Malay house. The Australian Journal of Anthropology, 19(1), 1-16. https://doi.org/10.1111/j.1835-9310.2008.tb00102.x

Montgomery, E. (2019). Gothic "Voodoo" in Africa and Haiti. eTropic 18 (1), 11-28.

Richey, N. J. (1986). An Interview with Thea Astley. South Central Review, 3(2), 90-102.

Stadler, J., Mitchell, P., \& Carleton, S. (2015). Imagined landscapes: geovisualizing Australian spatial narratives. Indiana University Press.

Shindo, K. (Director) (1964). Onibaba [Motion Picture]. Japan: Kindai Eiga Kyokai/Tokyo Eiga.

Vickers, A. (1977). Bali: A Paradise Created. Singapore: Periplus

Wallace, A.R. (1890) [1869]. The Malay Archipelago: The land of the orang-utan, and the bird of paradise. A narrative of travel, with studies of man and nature. (Volumes I \& II). London, UK \& New York, NY: Macmillan and Co. 